\section{Literature Ratified KNOWLedge Based View OF POULTRY SUPPLY ChAIN INTEGRATION CONCEPT}

\author{
A.S. Ariffina*, Z. Abas ${ }^{b}$, N. Balucha
}

aSchool of Technology Management and Logistics, College of Business, Universiti Utara Malaysia, 06010 Sintok, Kedah, Malaysia bSchool of Accounting, College of Business, Universiti Utara Malaysia, 06010 Sintok, Kedah, Malaysia
Article history

Received

30 July 2015

Received in revised form

30 September 2015

Accepted

31 October 2015

*Corresponding author ashabudin@uum.edu.my

\begin{abstract}
The evolution of relationships based on collaboration between business partners has become a fundamental subject of research in the area of supply chain management; including poultry supply chain integration. Study in this field has focused on a range of integration models. This study focuses on integration of systems, processes and strategy which is important for poultry supply chain business partners to recognize the benefits of closely associating supply to demand. One need to realize that these benefits are not easily achieved without constraints. A conclusion was made by proposing that 'Knowledge Based View' is a resource that can contribute value, towards knowledge generation, acquisition and application among members within and between organizations.

Keywords: Poultry farming, integration, knowledge based view, performance, supply chain management

\section{Abstrak}

Evolusi hubungkait berlandaskan kolaborasi di kalangan rakan kongsi perniagaan telah menjadi satu perkara asas dalam penyelidikan bidang pengurusan rantaian bekalan; termasuklah integrasi rantaian bekalan unggas. Kajian dalam bidang telah menumpukan kepada beberapa model integrasi. Kajian ini menumpukan kepada pengintegrasian sistem, proses dan strategi yang penting kepada rakan perniagaan rantaian bekalan unggas memperoleh manafaat yang berkait rapat dengan penawaran dan permintaan. Harus disedari bahawa manfaat tersebut tidak mudah diperoleh tanpa kekangan. Satu rumusan dibuat dengan mencadangkan bahawa pendekatan "Pandangan Berasaskan Pengetahuan" boleh menjadi sumber yang dapat menyumbang nilai kearah penjanaan, perolehan dan applikasi oleh ahli-ahli di kalangan dan di antara organisasi.
\end{abstract}

Katakunci: Perladangan unggas, integrasi, pandangan berasaskan pengetahuan, prestasi, pengurusan rantaian bekalan

(c) 2015 Penerbit UTM Press. All rights reserved

\subsection{INTRODUCTION}

The evolution of relationships based on collaboration between business partners has become a fundamental subject of research in the area of supply chain management [1] along integration $[2,3]$. Study in this field has focused on a range of integration modes including: linking logistics systems and methods with marketing strategy [4]; cross-functional integration in a supply chain context [5]; integration through connecting business partners' information systems to uphold transparency and information flow $[6,7,8]$; the use of internet technologies as an enabler of integration [9, 10]; achieving integration through coordinated products design, processes and the supply chain [11]; and sharing information to facilitate coordination of decisions across business partner networks [12].

This study focuses on integration of systems, processes and strategy which is important for poultry supply chain business partners to recognize the benefits of closely associating supply to demand. These benefits, however, are not essentially realized easily or without constraints. In specific, pursuing poultry supply chain integration involves collaboration that renders the boundaries of the organization ambiguous such that the economics of the association become subject to the good will of the members, and to their ability to control costs associated with coordination. Beside this background, the ability of poultry supply chain business partners to share, integrate and influence knowledge becomes a possible mechanism by which such constraints can be recognized, managed and/or mitigated [13].

This concept of the study covers the work of previous scholars in underlining the important role knowledge plays in facilitating effective management of the supply chain $[14,15,16]$. Hence, the development of clear strategies to support closer integration with business partners 
becomes a possible source of competitive advantage, and understanding how best to facilitate such integration becomes critical. Exploring the potential for a knowledge based approach to integration is consequently the objective of this paper. To ratify knowledge based view of poultry supply chain integration, this paper firstly presents the supply chain management perspective, secondly gives an overview of collaboration in supply chain; and follows by giving specific focus on supply chain in poultry industry. This paper further highlights the fundamental of knowledge based view of organization that perhaps could facilitate the supply chain ecosystem in poultry industry to reap benefits.

\subsection{THE SUPPLY CHAIN MANAGEMENT PERSPECTIVE}

Supply chain management (SCM) has recently become widespread among practitioners and academicians [17]. Business competition was strengthened in the 1990s and 2000s in global markets and supply chain management practices have been chartered to deliver the right products, to the right place, at the right time, in the right quantity, quality and condition to the growers at the lowest possible cost [18, 19, 20]. It has been suggested by Lau [21] that the recent business environment has been driven by constant changes, market unpredictability [22, 23, 24], rapid technology changes and shorter product life cycle [25]. This has resulted in a range of products and inconsistent global demand [26]. According to Porter [27] and Van Hoek [28], successful organizations remain competitive through various supply chain channel collaborations while adapting to changing market place conditions [29].

According to La Londe and Bernerd [30], the term SCM is usually used to describe the responsibilities of corporate executives, and it has become so prevalent that practically any publication with articles on manufacturing, distribution, customer management or transportation is bound to be about SCM or a topic that has to do with SCM [31]. As mentioned by Tyndall et al. [32], in operational terms, SCM involves the movement of materials and products. To some people, it is a management philosophy, while to others it is a management process, and some view it as an integrated system. Christopher [33] defines a supply chain as "a network of organizations that are involved, through upstream and downstream linkages, in the different processes and activities that produce value in the form of products and services in the hands of the ultimate customer."

The American Production and Inventory Control Society describe the supply chain as the connecting of processes across supplier-user industries, starting from the raw materials and ending with the consumption of the finished products. The supply chain comprises of all the internal and external functions of an industry which enable the value chain to produce items and supply services to, for instance, growers in the case of poultry farming. Some researchers have proposed the inclusion of an information system for the monitoring of all the activities in order to obtain a clearer definition of SCM. The Council of SCM Professionals (CSCMP), which is the leading organization for supply chain practitioners, researchers, and academicians, recently came up with a definition for SCM as the planning and management of all activities related to sourcing and procurement, conversion, and logistics management. What is most significant about this definition is that it also covers coordination and collaboration with supply chain partners who might be for poultry SCM: integrators, intermediaries, third party service providers, and growers. The SCM essentially combines supply and demand management within and across companies. Some scholars defined SCM as the chain connecting each component of the manufacturing and supply process, beginning from the raw materials and ending with the supply to the end user. This management philosophy concentrates on how businesses make use of their supply processes, technology, information, and skills to improve their competitive edge the coordination of the manufacturing, materials, logistics, and distribution and transportation functions within an organization SCM as an integrative philosophy to handle the overall movement of a distribution route from the supplier to the end user [34]. The following section gives an overview of collaboration in supply chain management.

\subsection{COLLABORATION IN THE SUPPLY CHAIN}

Collaboration in the Supply Chain theories has been developed to explain the best organization inter-firm associations. Transaction cost economics is based in the concept of bounded rationality, or the cognitive limits that constrain managers when choosing who they trust as business partners. This triggers the conjecture that all associations with business partners are subject to the risk of unscrupulous behavior (i.e., placing self-interest before the association, or being unreliable and untruthful in the service of your own interests), particularly if the interests of parties are also anticipated not to be affiliated [35]. In the supply chain management literature, this pattern has been designated as the model [36]. In fact, this approach to supplier associations is still extensively recognized as acceptable practice [37]. The rationale for this strategy has been to offset the possibility of unscrupulous behavior of business partners [35], or to neutralize bargaining power of suppliers and/or customers.

This theory has more recently been modified to 
accommodate the existence of networks and other hybrid collaborative governance forms [35]. Other theoretical perspectives have also emerged to explain why closer ties with trading partners provide strategic benefits that outweigh these risks [38]. Resource dependence theory would frame this relationship between trading partners as being governed by one firm seeking to control the resource(s) [39], or by cultivation of a partnership with the aim of gaining access to the resource(s) $[26,40]$. Strategic choice theory suggests that firms collaborate in pursuit of either growth through increasing market power [41], or efficiency through shared risk and economies of scale [42].

\subsection{SUPPLY CHAIN IN THE POULTRY INDUSTRY}

In the poultry industry, the main company within the supply chain framework is known as an integrator. This integrator has a vertically integrated supply chain, being the owner of most of the breeding, feeding, slaughtering and processing facilities making use of the latest technology and maintaining stringent hygienic standards in all its processes. It operates together with various distribution networks, from supermarkets to distributors and grocery stores. Its products are also delivered directly to eateries. The integrator is confident that its advantageous position in the domestic and foreign markets is due to the combined efforts of the whole team over a long period of time together with the strategy of the company in providing services and customized products. In conclusion, integrators, manufacturers, distributors, retailers and growers are parts of the supply chain. The growers are the most important part of the chain, since the main reason for the existence of any supply chain is to meet the needs of growers while generating profits for itself in the process [34]. The following section provides the fundamental of knowledge based view of the organization in facilitating the poultry supply chain ecosystem to recognize the benefits of integration of systems, processes and strategy for performance improvement.

\subsection{KNOWLEDGE BASED VIEW OF THE ORGANIZATION}

The knowledge based view (KBV) of the organization defines knowledge as the resource with the highest strategic value that can be generated, acquired and applied within and between firms [43]. This perspective builds on the Resource Based View (RBV) [44, 45] by proposing that knowledge encourages competitive advantage because knowledge resources have characteristics consistent with either; a) developing capabilities that are rare, valuable, imperfectly imitable and non-substitutable [44], or; b) being of themselves largely intangible resources consistent with possessing these characteristics. The KBV of the firm also supports the building of competencies through improving absorptive capacity. As firms' employees are involved in accessing knowledge through boundary spanning activities, recent empirical studies have shown the capacity for organizational learning is increased [46]. Further, the KBV has been applied to problems of definition of firm boundaries [47], governance of interorganizational relationships [43, 48], solution choice based on problem complexity [49], and collaborative supply chain practices [14].

The implications at the firm level are important because the value of a firm is not just a function of its constituent parts [50]. As suggested by Kogut [50], knowledge that resides outside of a firm cannot be assumed to be "public", and in fact may be embedded in the rules and norms of the relationships between firms. Knowledge externally held (if not a "public good") could therefore be expected to have characteristics similar to those of tacit knowledge in individuals (being difficult to codify and often having an important social context). It could also need to be supported by "credible rules" and "sanctioning mechanisms" (explicit codification of rules and conditions of engagement) [50] that provide an explicit structural governance framework. From a KBV perspective, collaboration between trading partners represents on one level a factor minimizing the cost and time for effective transfer of knowledge between firms, and at a deeper level a potential significant source of value. As such, the value of knowledge as a strategic resource enabling more effective management of the supply chain has been recognized $[13,14]$. The KBV perspective provides support for the proposition that collaboration is an effective strategy for accessing knowledge distributed amongst trading partners. Access to diverse sources of knowledge, therefore, promotes growth of the knowledge base (for the firm and/or the network) and builds competitive advantage [50].

The developing theme has been to re-define the supply chain as a "demand chain" to reflect the importance of customer focus and to highlight the importance of end-to-end coordination between supply and demand. This has triggered the investigation of integration between business partners from a more holistic perspective with the importance being on trying to govern the nature, importance and influence of integration across multiple tiers of the chain $[3,51,52,53]$. The findings of these studies vary, but some unifying themes emerge including: in rapidly growing industries trading partners can achieve efficiency and higher levels of customer satisfaction through a positive feedback loop between collaboration, information flows and the positive impact this has on the relationship [52]; high levels of integration intensity lead to the embedding of capabilities in organizational processes creating conditions conducive to the development of competitive advantage [53]; integration using web-based 
technologies was most effective for manufacturers when it included linking technologies with both suppliers and customers concurrently [51]; the broader the extent and degree of integration activity across the poultry supply chain (i.e., for integrators, growers and processors) the extent to which the integration with trading partners extends both upstream and downstream in the poultry supply chain, the stronger is the link to performance improvement [3].

\subsection{CONCLUSION}

The KBV of the organization defines knowledge as the resource with the highest deliberate value that can be generated, acquired and applied within and between organizations [43]. The knowledge based view of the organization proposes that the benefits of access to knowledge compensate the potential for opportunism in inter-firm collaborations. The outcome of this study will have some important implications for poultry farm managers when attempting to resolve the difficult issues associated with organizing inter-firm associations. Hence, it will show evidence that the integration of knowledge through collaborative practices with both growers and integrators provides substantial opportunities for organization to improve business performance. The evidence suggests that the effectiveness of collaboration based on integration of knowledge on the effectiveness of internal processes supports such collaboration. In this context, integration through knowledge sharing and collaboration becomes an important option, particularly where access to multiple sources of knowledge is required. In varied poultry business environments, where products rely on multiple sources of supply and distribution, such expertise reside in a different and distributed range of locations. The understanding of the dynamics of inter-firm governance is fundamental to the effective management of the individual organization.

\section{Acknowledgement}

The authors would like to thank the funding bodies of this study: Ministry of Education Malaysia under Knowledge Transfer Programme Grant, No.12477.

\section{References}

[1] Monczka, R. M., K. J. Petersen, R. B. Handfield and G. L. Ragatz. 1998. Success factors in strategic supplier alliances: The buying company perspective. Decision Sciences. 29 (3): 553- 577.

[2] Droge, C., J. Jayaram and S. K. Vickery. 2004. The effects of internal versus external integration practices on time-based performance and overall firm performance. Journal of Operations Management. 22: 557-573.

[3] Frohlich, M. T. and R. Westbrook. 2001. Arcs of integration: An international study of supply chain strategies. Journal of Operations Management. 19(2): 185-200.

[4] Alvarado, U. Y. and H. Kotzab. 2001. Supply Chain Management: The Integration of Logistics in Marketing. Industrial Marketing Management. 30(2): 183-198.

[5] Pagell, M. 2004. Understanding the factors that enable and inhibit the integration of operations, purchasing and logistics. Journal of Operations Management. 22(5): 459-487.

[6] Gunasekaran, A. and E. W. T. Ngai. 2004. Information systems in supply chain integration and management. European Journal of Operational Research. 159(2): 269-295.

[7] Kulp, S. C., H. L. Lee and E. Ofek. 2004. Manufacturer benefits from information integration with retail customers. Management Science. 50 (4): 431-444.

[8] Vickery, S. K., J. Jayaram, C. Droge and R. Calantone. 2003. The effects of an integrative supply chain strategy on customer service and financial performance: an analysis of direct and indirect relationships. Journal of Operations Management. 21: 523-539.

[9] Garcia-Dastugue, S. J. and D. M. Lambert. 2003. Internet-enabled coordination in the supply chain. Industrial Marketing Management, 32 (3): 251-263.

[10] Zeng, A. Z. and B. K. Pathak. 2003. Achieving information integration in supply chain management through B2B hubs: Concepts and analyses. Industrial Management and Data Systems. 103(9):

[11] Peterson, K. J., R. B. Handfield and G. L. Ragatz. 2005. Supplier integration into new product development: coordinating product, process and supply chain design. Journal of Operations Management. 23: 371-388.

[12] Sahin, F. and J. Robinson, E. Powell. 2005. Information sharing and coordination in make-toorder supply chains. Journal of Operations Management. 23 (6): 579-598.

[13] Hult, G. T., D. J. Ketchen and S. F. Slater. 2004. Information processing, knowledge development, and strategic supply chain performance. Academy of Management Journal. 47 (2): 241-253.

[14] Hult, G. T., D. J. Ketchen, S. T. Cavusgi and R. J. Calantone. 2006. Knowledge as a strategic resource in supply chains. Journal of Operations Management. 24: 458-475.

[15] Hult, G. T., D. J. Ketchen and M. Arrfelt. 2007. Strategic supply chain management: Improving performance through a culture of competitiveness and knowledge development. Strategic Management Journal. 28: 1035-1052.

[16] Ketchen, D. J. and G. T. Hult. 2007. Bridging organizational theory and supply chain management: The case of best value supply chains. Journal of Operations Management. 25: 573-580.

[17] Burgess, K., Singh, P. J., \& Korogla, R. 2006. Supply Chain Management: A structured literature review and implication for future research. International Journal of Operation \& Production Management. 26(7): 703-729.

[18] Coyle, J. J., Bardi, E. J., \& Langley, C. J. 2003. The Management Of Business Logistic. Canada: Thomson Learning.

[19] Li, S., Ragu_Nathan, B., Ragu-Nathan, T. S., \& Rao, S. S. 2006. The impact of supply chain management practices on competitive advantage and organizational performance. Omega. 34(1): 107-124.

[20] Lummus, R., Duclos, L. K., \& Vokurka, R. J. 2003. Supply chain flexibility: building a new model. 
Global Journal Of Flexible System Management. 4(4): 1-13.

[21] Lau, A. K. W., Yam, R. C. M., \& Tang, E. P. Y. 2010. Supply chain integration and product modularity: an empirical study of product performance for selected Hong Kong manufacturing industries. International Journal of Operations and Production Management. 30(1): 20-56.

[22] Kim, B. 2005. Mastering Business in Asia Supply Chain Management. Singapore: John Wiley and Sons Publishing.

[23] Swafford, P. M., Ghosh, S., \& Murthy, N. 2006. The antecedents of supply chain agility of a firm: scale development and model testing. Journal of Operation Management. 24(2): 170-188.

[24] Yusuf, Y. Y., Gunasekaran, A., Adeleye, E. O., \& Sivayoganathan, K. 2004. Agile supply chain capabilities: determinants of competitive objective. European Journal of Operation Research. 159(2): 379-392.

[25] Hyun, J. H., \& Ahn, B. H. 1992. A unifying framework for manufacturing flexibility. Manufacturing Review. 5(4): 251-260.

[26] Fisher, M. L. 1997. What is the right supply chain for your product? A simple framework can help you figure out the answer. Harvard Business Review. 75 (March-April), 105-117.

[27] Porter, M. E. 1990. The Competitive Advantage of Nation. Harvard Business Review. 68(2): 73-93.

[28] Van Hoek, R. I. 2001. The rediscovery of posphonement: a literature review and directions for research. Journal of Operation Management. 19: 161-184.

[29] Kumar, A., Fantazy, K. A., \& Kumar, U. 2006. Implementation and management framework for supply chain flexibility. Journal of Enterprise Information Management. 19(3): 303-319.

[30] La-Londe, \& Bernard, J. 1997. Supply Chain Management: Myth or Reality. Supply Chain Management Review. 1 (spring): 6-7.

[31] Ross, \& Frederick, D. 1998. Competing Through Supply Chain Management. New York: Chapman \& Hall.

[32] Tyndall, Gene, Gopal, C., Partsch, W., \& Kamauff, J. 1998. Supercharging Supply Chains: New Ways to Increase Value Through Global Operational Excellence. NY: John Wiley \& Sons.

[33] Christopher, M. 1994. Logistics and Supply Chain Management. New York, NY: Pitman Publishing.

[34] Chopra, S., \& Meindl, P. 2001. Supply Chain Management, Strategy, Planning and Operation. New Jersey, U.S: Prentice Hall.

[35] Williamson, O. E. 1991. Comparative Economic Organization: The Analysis of Discrete Structural Alternatives. Administrative Science Quarterly, 36 (2): 269-296.

[36] Dyer, J. H., D. S. Cho and W. J. Chu. 1998. Strategic Supplier Segmentation: The next best practice in supply chain management. California Management Review. 40 (2): 57-77.
[37] Kaufman, A., C. H. Wood and G. Theyel. 2000 Collaboration and technology linkages: A strategic supplier typology. Strategic Management Journal. $21(6)$ : 649-663.

[38] Barringer, B. R. and J. S. Harrison. 2000. Walking a tightrope: creating value through interorganizational relationships. Journal of Management. 26(3): 367-403.

[39] Thorelli, H. B. 1986. Networks: Between markets and hierarchies. Strategic Management Journal. 7: 37-51.

[40] Oliver, C. 1990. Determinants of inter-organizational relationships: Integration and future directions. Academy of Management Review. 15: 241-265.

[41] Harbison, J. R. and P. Pekar. 1998. Smart Alliances. San Francisco: Jossey-Bass.

[42] Powell, W. W. 1990. Neither mark nor hierarchy: network forms of organization. Research in Organizational Behavior. 12: 295-336.

[43] Grant, R. M. 1997. The knowledge-based view of the firm: Implications for management practice. Long Range Planning. 30(3): 450.

[44] Barney, J. 1991. Firm resources and sustained competitive advantage. Journal of Management. 17 (1): 99-120.

[45] Penrose, E. 1959. The theory of the growth of the firm. London: John Wiley.

[46] Teigland, R. and M. M. Wasko. 2003. Integrating Knowledge through Information Trading: Examining the Relationship between Boundary Spanning Communication and Individual Performance* Decision Sciences. 34(2): 261.

[47] Grant, R. M. and C. Baden-Fuller. 1995. A knowledge-based theory of inter-firm collaboration. Academy of Management Journal. 17.

[48] Heiman, B. and J. A. Nickerson. 2002. Towards reconciling transaction cost economics and the knowledge-based view of the firm: The context of inter-firm collaborations. International Journal of the Economics of Business. 9(1): 97.

[49] Nickerson, J. A. and T. R. Zenger. 2004. A knowledgebased theory of the firm: The problem solving perspective. Organization Science, 15 (6): 617-632.

[50] Kogut, B. 2000. The network as knowledge: Generative rules and the emergence of structure. Strategic Management Journal. 21 (3): 405-425.

[51] Frohlich, M. T. and R. Westbrook. 2002. Demand chain management in manufacturing and services: Web-based integration, drivers and performance. Journal of Operations Management. 20(6): 729-45.

[52] Heikkila, J. 2002. From supply to demand chain management: efficiency and customer satisfaction. Journal of Operations Management. 20(6): 747-767.

[53] Rosenzweig, E. D., A. V. Roth and J. W. Dean. 2003. The influence of integration strategy on competitive capabilities and business performance: An exploratory study of consumer products manufacturers. Journal of Operations Management. 21 (4): 437-456. 